\title{
Investigation of the impact of different ARC layers using PC1D simulation: application to crystalline silicon solar cells
}

\author{
Galib Hashmi ${ }^{1}$. Mohammad Junaebur Rashid ${ }^{1} \cdot$ Zahid Hasan Mahmood $^{1} \cdot$ Mahbubul Hoq $^{2}$. \\ Md. Habibur Rahman ${ }^{1}$
}

Received: 14 May 2018 / Accepted: 13 December 2018 / Published online: 24 December 2018

(c) The Author(s) 2018

\begin{abstract}
In this work, the impact of six different anti-reflection coating (ARC) layers has been investigated using PC1D simulation software. Simulation shows that the range of 500-700 $\mathrm{nm}$ would be suitable for designing an ARC. Designing a single-layer silicon nitride $\left(\mathrm{Si}_{3} \mathrm{~N}_{4}\right)$ ARC for $600 \mathrm{~nm}$ wavelength and with a thickness of $74.257 \mathrm{~nm}$, a silicon solar cell with 20.35\% efficiency has been simulated. Very closely followed by a $20.34 \%$ efficient silicon solar cell with $74.87 \mathrm{~nm}$ thick zinc oxide $(\mathrm{ZnO})$ ARC layer. Significant increase in efficiency has been observed by applying ARC in respect to not applying any kind of ARC. After efficient solar cell modeling, optimum efficiency of $20.67 \%$ is being achieved by using $\mathrm{SiO}_{2}$ surface passivation and $\mathrm{Si}_{3} \mathrm{~N}_{4} \mathrm{ARC}$ layer. The effects on voltage, current, photovoltaic efficiency, reflectivity and external quantum efficiency due to ARCs are also represented in this work.
\end{abstract}

Keywords Silicon solar cell $\cdot$ Anti-reflection coating (ARC) $\cdot$ Surface passivation $\cdot$ External quantum efficiency (EQE)

\section{Introduction}

One of the important issues of modern photovoltaic science is the optical losses in solar cell. In general, the optical losses account for about $7 \%$ efficiency loss in crystalline silicon solar cells [1]. So, the reduction in optical loss can have a huge positive impact on the conversion efficiency of silicon solar cells [2]. To reduce the optical loss, antireflection coating (ARC) plays a pivotal role in reducing reflection thus increasing the conversion efficiency of solar cells [3]. Anti-reflection coating reduces reflection by using the concept of phase changes in light and the dependence of the reflectivity on refractive index [4]. Since the fabrication of solar cell, many researchers used different ARCs, and still searching for a suitable ARC which can be used to improve the efficiency of solar cell $[5,6]$.

In the experimental study of ARC, Hocine et al. used $\mathrm{TiO}_{2}$ on crystalline silicon solar cell and found an increased

Galib Hashmi

galib_90@yahoo.com

1 Department of Electrical and Electronic Engineering, University of Dhaka, Dhaka, Bangladesh

2 Institute of Energy, AERE, Bangladesh Atomic Energy Commission, Savar, Dhaka, Bangladesh efficiency of $14.26 \%$, whereas without $\mathrm{TiO}_{2}$ the efficiency is limited to $11.24 \%$ [7]. Similarly Swatowska et al. [8] found an efficiency of $9.84 \%$ for a crystalline silicon solar cell without any ARC, and efficiencies of $14 \%$ and $14.25 \%$ are obtained using $\mathrm{TiO}_{2}$ and $\mathrm{Si}_{3} \mathrm{~N}_{4}$, respectively. In another study, Gee et al. [9] fabricated $15.55 \%$ and $16.03 \%$ efficient crystalline silicon solar using $\mathrm{TiO}_{2}$ and $\mathrm{ZnO}$, respectively. It thus turns out that $\mathrm{ZnO}$ would be an appropriate choice among those different ARCs. However, in all cases the wafer size, fabrication process and the condition were different. For instance, Hocine et al. used a $5 \times 5 \mathrm{~cm}^{2}$ wafer and Swatowska et al. considered $10 \times 10 \mathrm{~cm}^{2}$ wafer. Thus, comparing different works is really a challenge and result cannot be always conclusive. Moreover, designing ARC is a difficult task because of having so many options in parameters and materials. Little change in any aspect of ARC fabrication is challenging and costly. Therefore, researchers are now giving importance in doing simulation before actual fabrication. This is because through simulation, parameters can be defined and changed, similar environment can be considered in all cases, and selection of materials can be done quite easily. Moreover, theoretical investigations can be observed and studied in depth [10].

In the simulation study of ARC, Abdullah et al. [6] used Silvaco ATLAS to simulate silicon solar cell and obtained 
$4.72 \%$ efficient solar cell using $5 \mathrm{~nm} \mathrm{SiO}_{2}$ coating. Also, Lennie et al. used the similar tool and using double-layer $\mathrm{SiO}_{2} / \mathrm{Si}_{3} \mathrm{~N}_{4}$ anti-reflection coating the simulated solar cell exhibited an efficiency of $4.56 \%$ [11]. In Ref. [12-15], there were reports on simulation work using PC1D. Although same software was used in all their works, however, different ARCs and materials have been used by them. For instance, Moradi et al. [13] found $10.78 \%, 11.7 \%$ and $11.89 \%$ efficiency using $\mathrm{TiO}_{2}, \mathrm{ZnO}$ and $\mathrm{Si}_{3} \mathrm{~N}_{4}$ single-layer ARC, respectively, upon silicon solar cell. Also, the efficiencies of $13.37 \%$ and $13.59 \%$ are shown using $\mathrm{ZnO} / \mathrm{TiO}_{2}$ and $\mathrm{SiO}_{2} /$ $\mathrm{TiO}_{2}$ double-layer ARC, respectively. Using $\mathrm{ZnO}$ and $\mathrm{ZnS}$ ARC, Naser et al. simulated $18 \%$ and $19 \%$ efficient silicon solar cell with, respectively [15]. Thosar et al. simulated GaAs solar cell and showed that optimum short-circuit current can be found using $\mathrm{ZnO}$ and $\mathrm{MnO}$ ARC with $65 \mathrm{~nm}$ and $80 \mathrm{~nm}$ thicknesses, respectively [14]. Daniel N. Wright et al. reported 6.7\% efficient solar cell with $\mathrm{Si}_{3} \mathrm{~N}_{4}$ and $\mathrm{SiO}_{2}$ ARC upon crystalline silicon wafers [12]. Yahia et al. [16] performed simulation using MATLAB to see the effects of ARC on silicon substrate. From these researches, it indicates that MATLAB, PC1D, Silvaco ATLAS are used to simulate ARC of solar cell $[11,12,16]$. However, MATLAB software does not provide rigorous options of solar cell. On the other hand, PC1D is the most commercially available software used by many companies and universities [17]. Also, depending upon availability PC1D version 5.9 has been used to simulate solar cell with different types of ARC layers.

The vast majority of ARC simulation studies indicate generally two or three single-layer ARC upon silicon solar cell with 3-13\% efficiency [6, 12-16]. However, no reports were found showing the suitable wavelength for designing ARC and utilizing the concept of surface passivation upon ARC. Thus, to overcome all these issues and to perform a systematic study the main goal of this work is to simulate different types of ARCs and find out the suitable ARC for crystalline silicon solar cell. In this research, the impact without ARC and with six types of ARCs such as titanium dioxide $\left(\mathrm{TiO}_{2}\right)$, zinc oxide $(\mathrm{ZnO})$, zinc sulfide $(\mathrm{ZnS})$, silicon dioxide $\left(\mathrm{SiO}_{2}\right)$, silicon nitride $\left(\mathrm{Si}_{3} \mathrm{~N}_{4}\right)$ and silicon carbide $(\mathrm{SiC})$ has been investigated separately for crystalline silicon solar cell. Furthermore, simulation ranging from 250 to $1200 \mathrm{~nm}$ wavelength has been conducted to find out the most suitable wavelength required for designing ARC in solar cell. The reason for using these wavelengths is that the solar spectrum covers this range. Also, these wavelengths can be easily experimentally generated by UV-VIS-NIR spectrophotometer. Surface passivation upon ARC has been applied, and its impact has been investigated. The ARC simulation also gives insight into its effects on efficiency of solar cell. Moreover, the reflectivity for the wavelength range of 250-1250 nm of all the ARCs and external quantum efficiency has also been discussed in this paper.

\section{Simulation}

\section{Simulation without ARC}

To simulate the solar cell without ARC (Fig. 1a), a P-type silicon wafer with an area of $10 \times 10 \mathrm{~cm}^{2}$ and thickness of $300 \mu \mathrm{m}$ has been chosen. Afterward, the doping concentration of P-type has been selected to $1 \times 10^{17} \mathrm{~cm}^{-3}$. Then, the subsequent $\mathrm{N}$-type silicon layer thickness and doping concentration has been adjusted to $2 \mu \mathrm{m}$ and $1 \times 10^{18}$ $\mathrm{cm}^{-3}$, respectively [18]. In both P-type and N-type layers, a uniform doping profile has been assumed. Typically, the diffusion length of mono-crystalline silicon solar cell is 100-300 $\mu \mathrm{m}$ [19].

The diffusion length has to be less than the P-type wafer thickness of $300 \mu \mathrm{m}$. Note that the minimum minority carrier life time allows to limit the diffusion length less than $130 \mu \mathrm{m}$ [20]. Thus, for realistic approach the diffusion length of $200 \mu \mathrm{m}$ is considered here. To enhance the absorption,
Fig. 1 Simplified solar cell schematic without ARC (a) and with ARC (b) (a)

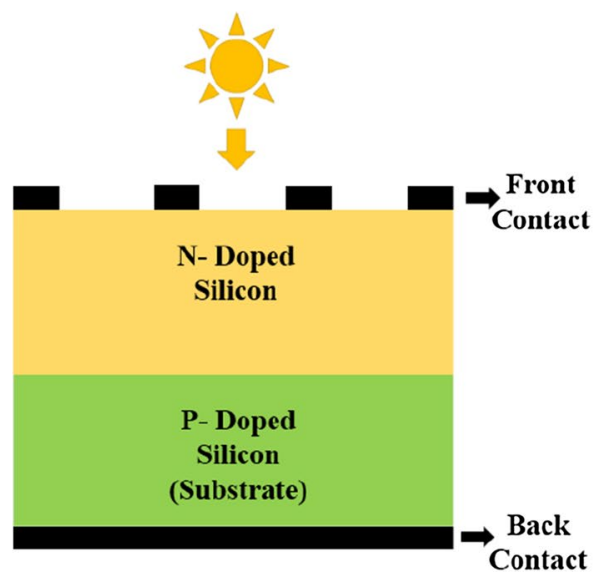

(b)
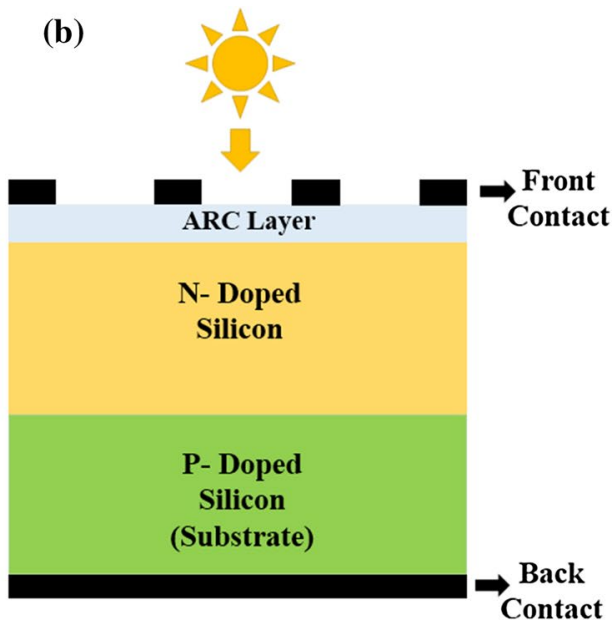
experimentally obtained textured wafer data were considered and inputted in this simulation. Both sides texturing option was enabled, and pyramid height of $1 \mu \mathrm{m}$ with equal angles of $54.74^{\circ}$ was considered for initial simulation. This is because in Ref. [18], the pyramid height of textured wafer height lies in the range of 1-3.5 $\mu \mathrm{m}$, obtained following the etching solution of $0.763 \mathrm{wt} \% \mathrm{KOH}-4 \mathrm{wt} \%$ IPA. Finally, to emulate the sun, AM (air mass) $1.5 \mathrm{G}$ and 100 number of time steps have been selected.

\section{Simulation with different ARCs}

To introduce ARC layer, the front surface optically coated option has been selected in the simulation. Then, the refractive index and thickness have been varied according to different ARCs. A simplified solar cell schematic with ARC is shown in Fig. 1b. Now, in order to design and understand the behavior of the ARC layer, the following equations [21-24] are necessary.

$\hat{n}(\lambda)=n(\lambda)+i \kappa(\lambda)$

where $\hat{n}(\lambda)$ is the complex refractive index. In complex refractive index, there is real part called real refractive index $n(\lambda)$, and an imaginary part called extinction coefficient $\kappa(\lambda)$ and both are functions of wavelength. The absorption coefficient $\alpha(\lambda)$ is related to the extinction coefficient $k$ by the following relation

$\alpha(\lambda)=\frac{4 \pi}{\lambda} \kappa(\lambda)$

It is clear that from Eq. 2 that the photons (or radiation) that are absorbed depend on the wavelength, thickness and nature of the medium [24].

Now the refractive index of ARC is $\eta_{\mathrm{ARC}}=\sqrt{\eta_{\mathrm{air}} \times \eta_{\mathrm{arc}}\left(\lambda_{0}\right)}$

and the thickness of ARC is $d=\frac{\lambda_{0}}{4 \times \eta_{\mathrm{ARC}}}$

Here, $\eta_{\text {air }}$ is the refractive index of air and $\eta_{\text {arc }}$ is the refractive index of an anti-reflection coating for a specific wavelength $\left(\lambda_{0}\right)$. Closer inspection of Eq. 3 shows that refractive index of ARC depends on refractive index of air as well as wavelength-dependent refractive index of a particular anti-reflection coating. Nevertheless, the value of right-hand side of Eq. 3 was not inputted in Eq. 3 or in the simulation. From Ref. [25-30], experimentally obtained $\eta_{\text {ARC }}$ values for different ARCs ranging from $250-1200 \mathrm{~nm}$ have been directly inputted in Eq. 4 and then in the simulation. Inputting wavelength $\left(\lambda_{0}\right)$ and corresponding $\eta_{\text {ARC }}$ value determines the associated optimum thickness values for each ARC. All the wavelengths, thicknesses, refractive indexes,
$V_{\mathrm{OC}}, I_{\mathrm{SC}}$ and efficiencies are tabulated in Table 1 . Then, with the optimum thickness and its corresponding $\eta_{\mathrm{ARC}}$ values, performances of different ARC layers have been studied through reflectance.

It is well known that high surface recombination rate reduces short-circuit current and thus the efficiency of solar cells. The surface recombination of photo-excited electron-hole pair takes place because of the dangling bonds at the top of surface. By reducing the number of dangling bonds, surface recombination can be lowered. Generally, a technique called thermal oxidation is used to reduce the surface recombination. In thermal oxidation technique, a "passivating" layer is grown thermally. The surface-passivating layer is fabricated with silicon oxide $\left(\mathrm{SiO}_{2}\right)$ which is used to passivate the surface. By applying only $\mathrm{O}_{2}$ gas, $\mathrm{SiO}_{2}$ layer can be grown upon $\mathrm{Si}_{3} \mathrm{~N}_{4}$ layer [31]. $\mathrm{As} \mathrm{Si}_{3} \mathrm{~N}_{4} \mathrm{ARC}$ shows the highest efficiency (discussed in"Effects of ARC" section), in this work, surface-passivated layer that is a simulation of $\mathrm{SiO}_{2}$ layer upon $\mathrm{Si}_{3} \mathrm{~N}_{4}$ ARC layer has been done.

In the simulation to see the external quantum efficiency and reflectivity of each ARC layer, excitation option has been modified from "one sun" to "SCAN-QE" (scan quantum efficiency). Furthermore, for better analysis, the number of time steps has been increased to 200 and the monochromatic wavelength spectrum range has been selected from 250 to $1250 \mathrm{~nm}$. Then, the simulation data of external quantum efficiency and reflectivity have been obtained and analyzed for every single ARC.

\section{Results and discussion}

\section{Effects of ARC}

By analyzing the data of different ARCs in Table 1, it is seen that changing wavelength along with its thickness also changes the $V_{\mathrm{OC}}, I_{\mathrm{SC}}$ and the efficiency of the solar cell. As absorption coefficient, refractive index, excitation coefficient are wavelength-dependent and cannot be changed easily, only thickness of the film can be optimized to get optimum absorption thus getting maximum $V_{\mathrm{OC}}, I_{\mathrm{SC}}$ and efficiency. In the case of $\mathrm{SiC}$, the table reveals that optimum thickness of $\mathrm{SiC}$ ARC is $36.159 \mathrm{~nm}$. For that thickness, maximum of $16.06 \%$ efficiency has been achieved. Maximum $V_{\mathrm{OC}}$ and $I_{\mathrm{SC}}$ value of $0.6779 \mathrm{~V}$ and $2.807 \mathrm{~A}$ is being achieved at the best efficiency. The optimum thickness and efficiency with $\mathrm{TiO}_{2}, \mathrm{ZnO}, \mathrm{ZnS}, \mathrm{SiO}_{2}$ and $\mathrm{Si}_{3} \mathrm{~N}_{4}$ ARC for solar cell are $62.396,78.411,63.479,101.351$ and $74.257 \mathrm{~nm}$ and $19.73 \%, 20.34 \%, 19.83 \%, 18.99 \%$ and $20.35 \%$, respectively. The reason for such efficiency increase is the reduction in light reflection [32]. As the thickness increases, $V_{\mathrm{OC}}, I_{\mathrm{SC}}$ and efficiency also increases up to the point where reflection is the lowest (Fig. 2). Then, $V_{\mathrm{OC}}, I_{\mathrm{SC}}$ and efficiency of 


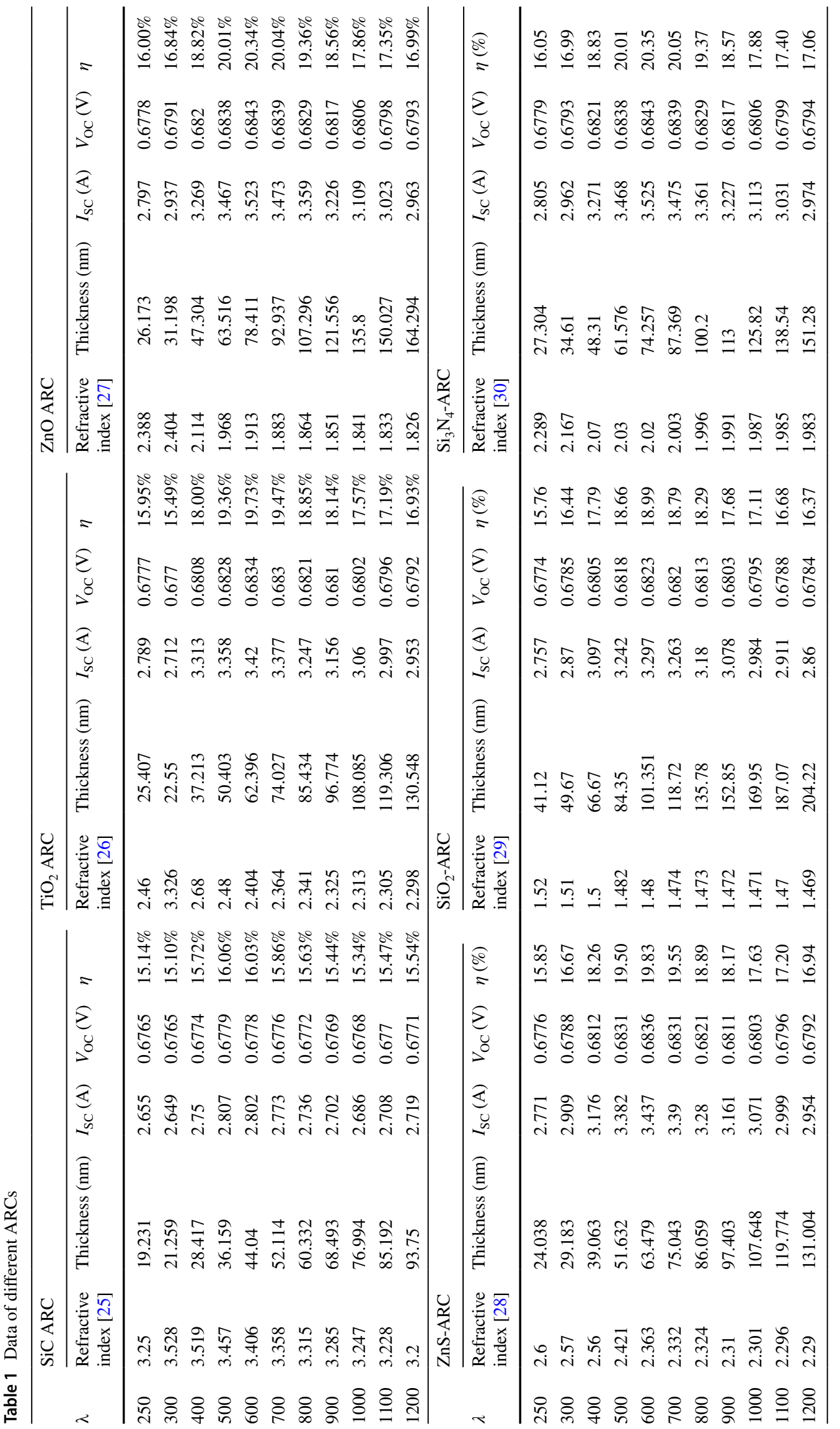


Reflectance Curves of Different ARC Layer

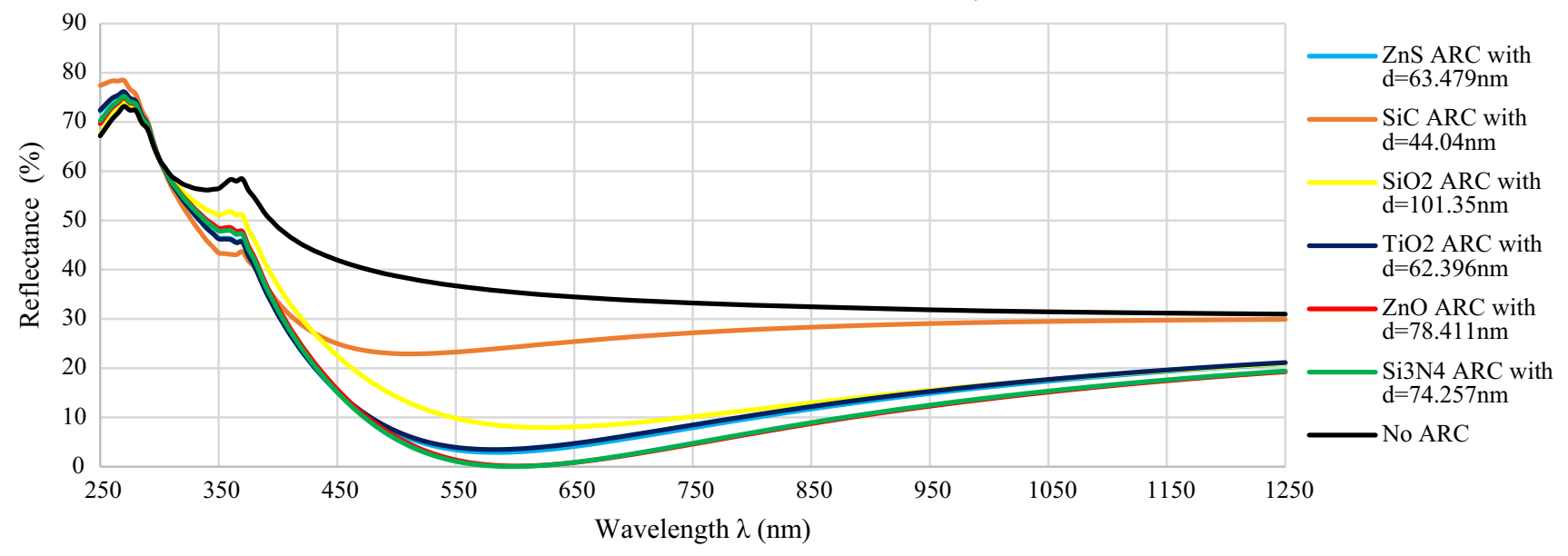

Fig. 2 Reflectance curves of different ARC layers designed for $600 \mathrm{~nm}$ wavelength with associated thickness

solar cell decrease as reflection increases. So, the optimization of thickness is required to get the lowest reflectance and to obtain the best $V_{\mathrm{OC}}, I_{\mathrm{SC}}$ and efficiency. Surprisingly, except SiC ARC, for all other ARCs the highest efficiency is achieved at a wavelength of $600 \mathrm{~nm}$. This can be seen in Fig. 2. It is seen that at a wavelength of $600 \mathrm{~nm}$, for $\mathrm{SiC}$, $\mathrm{TiO}_{2}, \mathrm{ZnO}, \mathrm{ZnS}, \mathrm{SiO}_{2}$ and $\mathrm{Si}_{3} \mathrm{~N}_{4}$ ARC the reflectance is $24.31 \%, 3.59 \%, 0.136 \%, 2.98 \%, 8.14 \%$ and $0.032 \%$, respectively. Overall, the lowest reflectance curve (green) is for $\mathrm{Si}_{3} \mathrm{~N}_{4}$ ARC closely followed by the Red reflectance curve of $\mathrm{ZnO}$ ARC. The Black curve signifies the general representation of a solar cell reflectance curve without any ARC. As can be seen from the Black curve, there are two peaks and afterward the curve decreases and then it becomes somewhat constant. But for all the reflectance curves with ARC, after two peaks the curves decrease rapidly up to a point then again increases. It is in good agreement of the results shown in Table 1, as the similar behavior is observed in the case of efficiency. The summary of Table 1 is for $74.257 \mathrm{~nm}$ thickness $\mathrm{Si}_{3} \mathrm{~N}_{4}$ ARC for solar cell shows the finest result with $20.35 \%$ efficiency. It is fascinating that without any ARC, the efficiency of solar cell is $14.02 \%$. So, after applying ARC significant increase in efficiency is observed. Now to find out the explanation of decrease in reflectance up to a certain point and then an increase in the reflectance curve in Fig. 2, the wavelength and associated thickness of $\mathrm{Si}_{3} \mathrm{~N}_{4}$
ARC have been varied and the result is tabulated in Table 2 . The reason for choosing only $\mathrm{Si}_{3} \mathrm{~N}_{4} \mathrm{ARC}$ is that it has the best solar cell efficiency mentioned earlier (Table 1). It is seen form Table 2 that if $\mathrm{Si}_{3} \mathrm{~N}_{4}$ ARC is designed for $500 \mathrm{~nm}$ wavelength and with $61.576 \mathrm{~nm}$ thickness then the reflectance is lowest at $500 \mathrm{~nm}$. At $500 \mathrm{~nm}, \mathrm{Si}_{3} \mathrm{~N}_{4}$ ARCs reflectance is $0.045 \%$, whereas at 600 and $700 \mathrm{~nm}$ the reflectance is $3.677 \%$ and $8.957 \%$, respectively. Similarly, if $\mathrm{Si}_{3} \mathrm{~N}_{4} \mathrm{ARC}$ is designed for $600 \mathrm{~nm}$ wavelengths and with $74.257 \mathrm{~nm}$ thickness then reflectance at 500, 600 and $700 \mathrm{~nm}$ is $5.537 \%$, $0.0317 \%$ and $2.644 \%$, respectively. It is interesting that the particular wavelength and associated thickness for which the ARC is designed show the lowest reflectance. So, in all the ARC reflectance curves in Fig. 2, the reflectance decreases after the two peaks up to $600 \mathrm{~nm}$ wavelength and associated thickness for which the ARC has been designed. It is suffice to say after observing all the reflectance curves in Fig. 2 that when the reflection of light from the surface is reduced, the efficiency of solar cell is increased.

\section{Effects of surface passivation}

As stated earlier, solar cell with $\mathrm{Si}_{3} \mathrm{~N}_{4} \mathrm{ARC}$ has the best efficiency of $20.35 \%$, and surface passivation $\left(\mathrm{SiO}_{2}\right.$ layer) has been applied only upon this layer. Table 1 indicates that the optimum thickness of $\mathrm{SiO}_{2}$ and $\mathrm{Si}_{3} \mathrm{~N}_{4}$ layer is $101.351 \mathrm{~nm}$

Table 2 Data of $\mathrm{Si}_{3} \mathrm{~N}_{4} \mathrm{ARC}$

\begin{tabular}{lllll}
\hline ARC $\left(\mathrm{Si}_{3} \mathrm{~N}_{4}\right)$ & $\begin{array}{l}\text { Reflectance }(\%) \text { at } \\
500 \mathrm{~nm} \text { wavelength }\end{array}$ & $\begin{array}{l}\text { Reflectance }(\%) \text { at } \\
600 \mathrm{~nm} \text { wavelength }\end{array}$ & $\begin{array}{l}\text { Reflectance (\%) at } \\
700 \mathrm{~nm} \text { wavelength }\end{array}$ & Efficiency (\%) \\
\hline$\lambda=500 \mathrm{~nm}, d=61.576 \mathrm{~nm}$ & 0.045 & 3.677 & 8.957 & 20.01 \\
$\lambda=600 \mathrm{~nm}, d=74.257 \mathrm{~nm}$ & 5.537 & 0.0317 & 2.644 & 20.35 \\
$\lambda=700 \mathrm{~nm}, d=87.369 \mathrm{~nm}$ & 17.716 & 3.462 & 0.094 & 20.05 \\
\hline
\end{tabular}


and $74.257 \mathrm{~nm}$, respectively; thus, these two thicknesses were used in the simulation for surface passivation first and after completion of simulation the data were tabulated in Table 3. It indicates that maximum of $20.42 \%$ efficiency can be achieved by applying $101.351-\mathrm{nm}$-thick $\mathrm{SiO}_{2}$ layer upon 74.257-nm-thick $\mathrm{Si}_{3} \mathrm{~N}_{4}$ layer. However, through optimization one can reduce the layer thickness as can be seen from Table 3 that optimum efficiency of $20.67 \%$ is being achieved with 57-nm-thick $\mathrm{SiO}_{2}$ layer upon 58-nm-thick $\mathrm{Si}_{3} \mathrm{~N}_{4}$ ARC. This is because the $\mathrm{SiO}_{2}$ surface-passivated layer upon $\mathrm{Si}_{3} \mathrm{~N}_{4}$ ARC behaves like double-layer ARC and for that refractive index, thickness and reflectivity of the ARC layer follow a complex equation. For details, see Ref. [33]. It also signifies that optimum surface passivation reduces both $\mathrm{SiO}_{2}$ and $\mathrm{Si}_{3} \mathrm{~N}_{4}$ layer thickness; thus, in actual fabrication process overall fabrication cost may be reduced. The reflectivity curve in Fig. 3 also confirms the complex behavior of surface-passivated layer. Unlike the $\mathrm{Si}_{3} \mathrm{~N}_{4} \mathrm{ARC}$ (green curve), there is an increase in reflectance around $600 \mathrm{~nm}$ regions for surface-passivated blue curve, whereas the surface-passivated Red reflectance curve overall has lower reflectance in the $250-1250 \mathrm{~nm}$ wavelength region than other reflectance curves. The fact is that the efficiency is increased due to the reduction in reflection light and occurred because of surface passivation process.

Result of external quantum efficiency (EQE) is shown in Fig. 4. Upon inspection of Fig. 4, it can be concluded that after utilization of ARC, EQE has increased significantly. This increase is due to the reduction in reflection for applying ARC. Although from 425 to $640 \mathrm{~nm}$ the EQE of
$\mathrm{Si}_{3} \mathrm{~N}_{4}$ ARC (Black) curve is slightly greater than EQE of $\mathrm{Si}_{3} \mathrm{~N}_{4}$ ARC (Red) curve, from $640 \mathrm{~nm}$ and overall the EQE is showing the best result for the surface-passivated curve (Red). It is adequate to say, surface passivation increases the overall EQE of solar cell by reducing the number of dangling bonds thus reducing the recombination effects $[34,35]$.

\section{Conclusion}

The effect of different single-layer ARCs has been investigated using PC1D simulation software. It is seen in the literature that Gee et al. fabricated $15.55 \%$ and $16.03 \%$ efficient solar cell with $\mathrm{TiO}_{2}$ and $\mathrm{ZnO}$ ARC, respectively. However, in the simulation it is seen that $15.49 \%$ and $16.00 \%$ efficient solar cell has been obtained with $\mathrm{TiO}_{2}$ and $\mathrm{ZnO}$ ARC, respectively. To obtain these efficiencies, thickness of with $\mathrm{TiO}_{2}$ and $\mathrm{ZnO}$ ARC was considered $22.55 \mathrm{~nm}$ and $26.173 \mathrm{~nm}$, respectively. Efficiency can be further increased with $\mathrm{TiO}_{2}$ and $\mathrm{ZnO}$ ARC in the simulation by optimizing thickness and other parameters. The same thing can be said for other ARCs also. So it can be said that there is little difference in the result obtained from simulation than experimental results. Simulation shows that the range of 500-700 nm would be suitable for designing an ARC. Among $\mathrm{TiO}_{2}, \mathrm{ZnO}, \mathrm{ZnS}, \mathrm{SiO}_{2}, \mathrm{Si}_{3} \mathrm{~N}_{4}$ and $\mathrm{SiC} \mathrm{ARC}, \mathrm{Si}_{3} \mathrm{~N}_{4}$ ARC exhibits the best performance with an efficiency of $20.35 \%$ for crystalline silicon solar cell. Then, $\mathrm{ZnO}$ ARC is indicating the second best performance with an efficiency of 20.34\%. However, without any ARC the efficiency of solar

Table 3 Associated parameters of solar cell with surface-passivated ARCs

\begin{tabular}{lllllr}
\hline Surface passivation conditions & $\begin{array}{l}\text { Short-circuit cur- } \\
\text { rent }\left(I_{\mathrm{SC}}\right)\end{array}$ & $\begin{array}{l}\text { Open-circuit volt- } \\
\text { age }\left(V_{\mathrm{OC}}\right)\end{array}$ & Max power $(\mathrm{W})$ & Fill factor $(\mathrm{FF})$ & Efficiency $(\%)$ \\
\hline $101.351 \mathrm{~nm} \mathrm{SiO}_{2} / 74.257 \mathrm{~nm} \mathrm{Si}_{3} \mathrm{~N}_{4} \mathrm{ARC}$ & $3.535 \mathrm{~A}$ & $0.6844 \mathrm{~V}$ & 2.042 & 0.8440 & 20.42 \\
$57 \mathrm{~nm} \mathrm{SiO}_{2} / 58 \mathrm{~nm} \mathrm{Si}_{3} \mathrm{~N}_{4} \mathrm{ARC}$ & $3.576 \mathrm{~A}$ & $0.6848 \mathrm{~V}$ & 2.067 & 0.8441 & 20.67 \\
\hline
\end{tabular}

Fig. 3 Reflectance curves of ARC and surface-passivated ARC layer

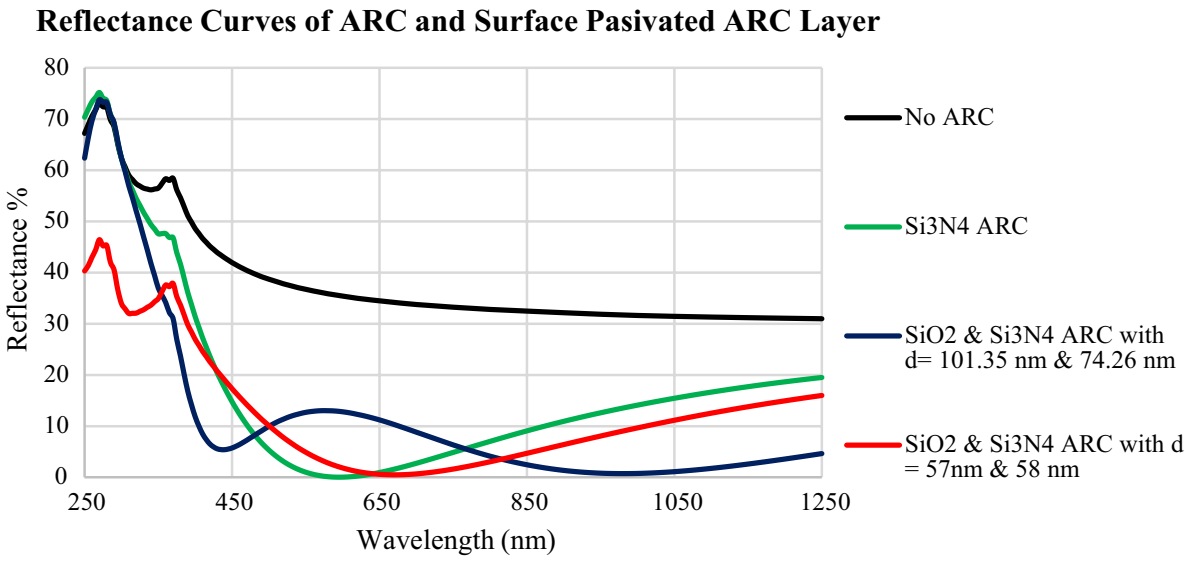


Fig. 4 External quantum efficiency curves
External Quantum Efficiency (EQE)

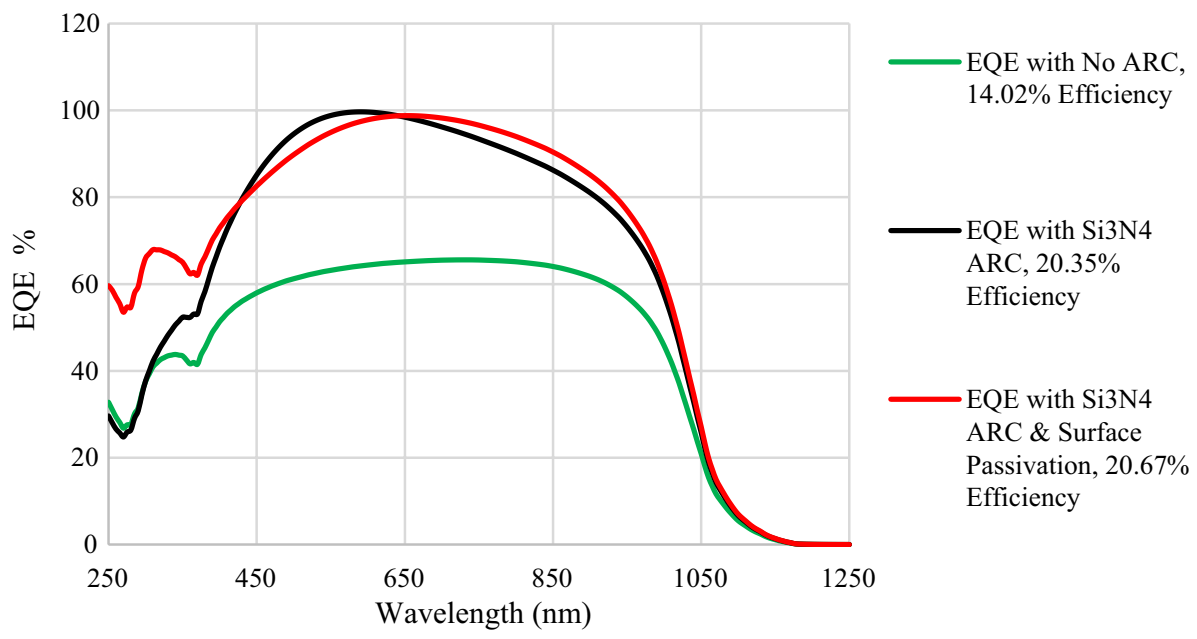

cell is $14.02 \%$. So, after applying ARC significant increase in efficiency is observed. The reason for such efficiency increase is due to the reduction in reflection. So applying anti-reflection coating would be a good choice to enhance the efficiency. Also, $\mathrm{SiO}_{2}$ surface passivation treatment on $\mathrm{Si}_{3} \mathrm{~N}_{4}$ ARC layer was performed and $20.67 \%$ efficient solar cell is being achieved. Increase in EQE and decrease in reflectance also confirm that surface-passivated layer upon ARC increases the efficiency of solar cell.

Acknowledgements The authors express their thanks to University of New South Wales, Australia, for providing PC1D software. This work has been supported by the scholarship program of the ICT Division, Ministry of Posts, Telecommunications and IT, Government of Bangladesh. Finally, the authors also express their gratitude to the Faculty of Engineering and Technology and Department of Electrical and Electronic Engineering, University of Dhaka, for contributing to do this kind of research.

Open Access This article is distributed under the terms of the Creative Commons Attribution 4.0 International License (http://creativeco mmons.org/licenses/by/4.0/), which permits unrestricted use, distribution, and reproduction in any medium, provided you give appropriate credit to the original author(s) and the source, provide a link to the Creative Commons license, and indicate if changes were made.

\section{References}

1. Fahim, N., Ouyang, Z., Zhang, Y., Jia, B., Shi, Z., Gu, M.: Efficiency enhancement of screen-printed multicrystalline silicon solar cells by integrating gold nanoparticles via a dip coating process. Opt. Mater. Express 2(2), 190 (2012)

2. Park, H., Kwon, S., Lee, J., Lim, H., Yoon, S., Kim, D.: Improvement on surface texturing of single crystalline silicon for solar cells by saw-damage etching using an acidic solution. Sol. Energy Mater. Sol. Cells 93(10), 1773-1778 (2009)
3. Hiller, J., Mendelsohn, J., Rubner, M.: Reversibly erasable nanoporous anti-reflection coatings from polyelectrolyte multilayers. Nat. Mater. 1(1), 59-63 (2002)

4. Kosyachenko, L.: Solar Cells. InTech, Rijeka (2011)

5. Uzum, A., Kuriyama, M., Kanda, H., Kimura, Y., Tanimoto, K., Fukui, H., Izumi, T., Harada, T., Ito, S.: Sprayed and spin-coated multilayer antireflection coating films for nonvacuum processed crystalline silicon solar cells. Int. J. Photoenergy 2017, 1-5 (2017)

6. Abdullah, H., Lennie, A., Ahmad, I.: Modelling and simulation single layer anti-reflective coating of $\mathrm{ZnO}$ and $\mathrm{ZnS}$ for silicon solar cells using silvaco software. J. Appl. Sci. 9(6), 1180-1184 (2009)

7. Hocine, D., Belkaid, M., Pasquinelli, M., Escoubas, L., Simon, J., Rivière, G., Moussi, A.: Improved efficiency of multicrystalline silicon solar cells by $\mathrm{TiO} 2$ antireflection coatings derived by APCVD process. Mater. Sci. Semicond. Process. 16(1), 113-117 (2013)

8. Swatowska, B., Stapinski, T., Drabczyk, K., Panek, P.: The role of antireflective coatings in silicon solar cells-the influence on their electrical parameters. Opt. Appl. 41(2), 487-492 (2011)

9. Gee, J., Gordon, R., Liang, H.: Optimization of textured-dielectric coatings for crystalline-silicon solar cells. In: Photovoltaic Specialists Conference, 1996, Washington, DC, USA (1996)

10. Research and development in simulation-based engineering and science. Wtec.org. [Online]. http://www.wtec.org/sbes/. Accessed 31 Oct 2017

11. Lennie, A., Abdullah, H., Shila, Z., Hannan, M.: Modelling and simulation of $\mathrm{SiO}_{2} / \mathrm{Si}_{3} \mathrm{~N}_{4}$ as anti-reflecting coating for silicon solar cell by using silvaco software. World Appl. Sci. J. 11(7), 786-790 (2010)

12. Wright, D., Marstein, E., Holt, A.: Double Layer Anti-Reflective Coatings for Silicon Solar Cells, pp. 1237-1240. FL, USA, Lake Buena Vista (2005)

13. Moradi, M., Rajabi, Z.: Efficiency enhancement of Si solar cells by using nanostructured single and double layer anti-reflective coatings. J. Nanostruct. 3(3), 365-369 (2013)

14. Thosar, A., Thosar, M., Khanna, R.: Optimization of anti-reflection coating for improving the performance of GaAs solar cell. Indian J. Sci. Technol. 7(5), 637-641 (2014)

15. Naser, N., Mustafa, B.: Single layer anti-reflective (AR) coating silicon solar cells using simulation program. ZANCO J. Pure Appl. Sci. 28(6), 39-43 (2016) 
16. Yahia, K.: Simulation of multilayer layer antireflection coating for visible and near IR region on silicon substrate using matlab program. J. Al-Nahrain Univ. 12(4), 97-103 (2009)

17. PC1D, PVEducation. [Online]. http://www.pveducation.org/ pvcdrom/characterisation/pc1d. Accessed: 31 Oct 2017

18. Hashmi, G., Akand, A., Hoq, M., Rahman, H.: Study of the enhancement of the efficiency of the monocrystalline silicon solar cell by optimizing effective parameters using PC1D simulation. Silicon 10(4), 1653-1660 (2018)

19. Hashmi, G., Akand, M., Basher, M., Hoq, M., Rahman, M.: Fabrication of crystalline silicon solar cell in Bangladesh: limitations and remedies. Int. J. Sci. Eng. Res. 7(6), 581-586 (2016)

20. Solanki, C.: Solar Photovoltaics: Fundamentals, Technologies and Applications, 3rd edn. PHI Learning Private Limited, Delhi (2015)

21. In: Luque, A. Sala, G., Palz, W., Santos, G., Helm, P. (eds.) Tenth E.C. Photovoltaic Solar Energy Conference. Springer, Dordrecht (1991)

22. Akaltun, Y., Yıldırım, M., Ateş, A., Yıldırım, M.: The relationship between refractive index-energy gap and the film thickness effect on the characteristic parameters of CdSe thin films. Opt. Commun. 284(9), 2307-2311 (2011)

23. Hébert, M.: Reflection and transmission of light by a flat interface, Fresnel's formulae. Paristech. Institutoptique.fr [Online]. http://paristech.institutoptique.fr/site.php?id=797\&fileid=11468 (2013). Accessed 27 Feb 2018

24. Absorption and extinction coefficient theory-University of Reading. Reading.ac.uk. [Online]. http://www.reading.ac.uk/ir-subst rateopticaltheory-absorptionandextinctioncoefficienttheory.aspx. Accessed 02 Mar 2018

25. SiC. Refractiveindex.info. [Online]. https://refractiveindex.info/ tmp/data/main/SiC/Larruquert.txt. Accessed 14 Jan 2018

26. $\mathrm{TiO}_{2}$. Refractiveindex.info. [Online]. https://refractiveindex.info/ tmp/data/main/TiO2/Siefke.txt. Accessed 14 Jan 2018

27. Fanni, L., Delaup, B., Niesen, B., Milstein, Y., Shachal, D., Morales-Masis, M., Nicolay, S., Ballif, C.: Tuning the porosity of zinc oxide electrodes: from dense to nanopillar films. Mater. Res. Express 2(7), 1-7 (2015)

28. Palik, E., Ghosh, G.: Handbook of Optical Constants of Solids. Academic Press, Orlando (1985)

29. Refractive index of $\mathrm{SiO}_{2}$. Refractive index info. [Online]. https:// refractiveindex.info/?shelf $=$ main $\&$ book $=\mathrm{SiO}_{2} \&$ page $=\mathrm{Gao}$. Accessed 31 Oct 2017

30. Refractive index of $\mathrm{Si}_{3} \mathrm{~N}_{4}$. Refractive index info. [Online]. https:// refractiveindex.info/?shelf $=$ main $\&$ book $=\mathrm{Si}_{3} \mathrm{~N}_{4}$ \&page $=$ Philipp. Accessed 31 Oct 2017

31. Fränz, I., Langheinrich, W.: Conversion of silicon nitride into silicon dioxide through the influence of oxygen. Solid-State Electron. 14(6), 499-505 (1971)

32. Kumaragurubaran, B., Anandhi, S.: Reduction of reflection losses in solar cell using anti reflective coating. In: International Conference on Computation of Power, Energy, Information and Communication (ICCPEIC), Chennai, India (2014)

33. Double Layer Anti Reflection CoatingsIPVEducation. Pveducation.org. [Online]. http://www.pveducation.org/pvcdrom/doubl e-layer-anti-reflection-coatings. Accessed 31 Oct 2017

34. Davidson, L.: Strategies for high efficiency silicon solar cells. Iowa Research Online. [Online]. http://ir.uiowa.edu/etd/5452 (2018). Accessed 04 Apr 2018

35. Ju, M., Balaji, N., Park, C., Thanh Nguyen, H., Cui, J., Oh, D., Jeon, M., Kang, J., Shim, G., Yi, J.: The effect of small pyramid texturing on the enhanced passivation and efficiency of single c-Si solar cells. RSC Adv. 6(55), 49831-49838 (2016)

Publisher's Note Springer Nature remains neutral with regard to jurisdictional claims in published maps and institutional affiliations. 